\title{
MENINGKATKAN MOTIVASI BELAJAR SISWA \\ MELALUI LAYANAN PENGUASAAN KONTEN DENGAN TEKNIK MULTIMEDIA PADA SISWA KELAS VIII B SMPNEGERI 2 JUWIRING
}

\author{
${ }^{1}$ Ikawati Minto Palupi \\ ${ }^{1}$ SMP Negeri 2 Juwiring Klaten \\ e-mail: ikawati_palupi_cutie@yahoo.co.id
}

\begin{abstract}
ABSTRAK
Tujuan penelitian ini adalah : 1) untuk meningkatkan motivasi belajar melalui layanan penguasaan konten dengan teknik multimedia pada siswa kelas VIII B SMP Negeri 2 Juwiring; 2) untuk mendeskripsikan peningkatan motivasi belajar melalui layanan penguasaan konten dengan teknik multimedia pada siswa kelas VIII B SMP Negeri 2 Juwiring. Subjek penelitian ini adalah siswa kelas VIII B SMP Negeri 2 Juwiring yang berjumlah 18 siswa. Penelitian ini merupakan penelitian tindakan bimbingan konseling yang berbasis penelitian tindakan kelas. Penelitian ini menggunakan dua siklus dengan masing-masing siklus memiliki empat kegiatan utama yaitu : planning (perencanaan), action (tindakan), observation (observasi) dan reflexion (refleksi). Penelitian ini dilakukan dengan dua siklus, yang terdiri dari dua pertemuan tiap siklus. Metode pengumpulan data menggunakan skala motivasi belajar, observasi dan dokumentasi. Analisis data penelitian ini menggunakan teknik analisis deskriptif. Berdasarkan penelitian ini maka simpulannya adalah : 1) motivasi belajar siswa dapat ditingkatkan melalui layanan penguasaan konten dengan teknik multimedia; 2) terdapat perubahan yang positif yaitu berupa peningkatan yang signifikan pada motivasi belajar siswa setelah diberi layanan penguasaan konten dengan teknik multimedia. Hal ini dibuktikan dengan : 1) terjadi peningkatan motivasi belajar siswa dari prosentase skor antara $40 \%$ - 55\% yang termasuk dalam kategori rendah menjadi antara $70 \%-85 \%$ yang termasuk dalam kategori tinggi.
\end{abstract}

Kata kunci : layanan penguasaan konten, teknik multimedia, motivasi belajar

\section{ABSTRACT}

The aims of this study are: 1) to increase learning motivation through content mastery services with multimedia techniques at VIII B students of Junior High School 2 Juwiring; 2) to describe the increase of learning motivation through content mastery services with multimedia techniques at VIII B students of Junior High School 2 Juwiring. The subjects of this study were 18 students of VIII B Junior High School 2 Juwiring. This research is a guidance counseling action research based on classroom action research. This study uses two cycles with each cycle have four main activities, namely: planning, action, observation and reflexion. This research was conducted in two cycles, which consisted of two meetings per cycle. The data collection method uses a scale of learning motivation, observation and documentation. Analysis of the data in this study uses descriptive analysis techniques. Based on this research, the conclusions are: 1) student's learning motivation can be improved through content mastery services 
with multimedia techniques; 2) there is a positive change in the form of a significant increase in student's learning motivation after being given content mastery services with multimedia techniques. This is evidenced by: 1) an increase in student's learning motivation from the percentage score between $40 \%$ - 55\% included in the low category to between $70 \%-85 \%$ included in the high category.

Keywords : content mastery services, learning motivation, multimedia techniques

\section{PENDAHULUAN}

Motivasi merupakan salah satu faktor yang penting dalam proses pembelajaran. Keberhasilan suatu proses pembelajaran dipengaruhi oleh motivasi belajar. Motivasi adalah syarat mutlak untuk belajar (Purwanto, 2017: 60). Siswa yang memiliki banyak potensi tidak akan medapatkan hasil yang optimal jika tidak memiliki motivasi belajar. Tanpa adanya motivasi belajar siswa akan malas melakukan kegiatan belajar yang akan menyebabkan rendahnya prestasi belajar. Menurut Iskandarwassid \& Sunendar (2018: 136) meskipun seorang peserta didik mempunyai kecakapan belajar yang tinggi, ia akan kurang berhasil dalam belajarnya jika motivasinya lemah.

Saat ini banyak faktor yang menyebabkan siswa malas belajar. Salah satu faktor yang paling banyak mempengaruhi yaitu adanya kemajuan teknologi. Kemajuan teknologi yang seharusnya dapat memfasilitasi kegiatan belajar sering menjadi penyebab siswa malas belajar. Adanya media sosial menyebabkan siswa sering tidak konsentrasi dalam belajar. Selain itu, game online juga menyebabkan siswa malas untuk melakukan kegiatan belajar. Oleh karena itu, motivasi belajar hendaknya ditingkatkan agar kegiatan belajar dapat optimal sehingga tujuan pembelajaran dapat tercapai.

Pada kenyataannya siswa kelas VIII B SMP Negeri 2 Juwiring Klaten memiliki motivasi belajar yang masih tergolong rendah. Hasil observasi yang dilakukan oleh peneliti terhadap siswa kelas VIII B di SMP Negeri 2 Juwiring menunjukkan bahwa sebanyak 64\% siswa kelas VIII B tersebut memiliki motivasi belajar rendah. Apabila kondisi tersebut tidak segera diatasi, maka tidak menutup kemungkinan akan memunculkan dampak yang lebih luas misalnya siswa kurang bertanggung jawab terhadap tugasnya dan prestasi belajar menurun. Berdasarkan analisa terhadap fakta tersebut maka diperlukan langkah konkrit yang harus dilaksanakan oleh peneliti, yaitu membantu siswa dalam meningkatkan motivasi belajar.

Layanan bimbingan dan konseling memiliki fungsi yang sangat penting dalam membantu siswa meningkatkan motivasi belajar. Layanan bimbingan dan konseling yang sesuai untuk digunakan dalam penelitian ini adalah layanan penguasaan konten dengan teknik multimedia. Layanan penguasaan konten merupakan layanan yang 
diberikan kepada siswa untuk menguasai kemampuan atau kompetensi tertentu melalui kegiatan belajar. Teknik multimedia dipilih karena dalam pelaksanaan layanan ini materi harus disajikan secara menarik dan mudah dipahami oleh siswa. Materi disajikan dengan power point dan tayangan video/film yang didalamnya mengandung aspekaspek motivasi belajar.

Berdasarkan uraian di atas maka tujuan penelitian ini ada dua, yaitu : 1) meningkatkan motivasi belajar melalui layanan penguasaan konten dengan teknik multimedia pada siswa kelas VIII B SMP Negeri 2 Juwiring; 2) mendeskripsikan peningkatan motivasi belajar melalui layanan penguasaan konten dengan teknik multimedia pada siswa kelas VIII B SMP Negeri 2 Juwiring. Rumusan masalah dalam penelitian ini yaitu : 1) apakah motivasi belajar dapat ditingkatkan melalui layanan penguasaan konten dengan teknik multimedia pada siswa kelas VIII B SMP Negeri 2 Juwiring?; 2) bagaimana deskripsi peningkatan motivasi belajar melalui penerapan layanan penguasaan konten dengan teknik multimedia pada siswa kelas VIII B SMP Negeri 2 Juwiring?

\section{METODE}

Penelitian ini merupakan penelitian tindakan bimbingan konseling yang berbasis penelitian tindakan kelas. Penelitian ini menggunakan dua siklus dengan masing-masing siklus memiliki empat kegiatan utama yaitu : planning (perencanaan), action (tindakan), observation (observasi) dan reflexion (refleksi). Penelitian ini dilakukan dengan dua siklus, yang terdiri dari dua pertemuan tiap siklus. Teknik pengumpulan data menggunakan skala motivasi belajar, observasi dan dokumentasi. Analisis data penelitian ini menggunakan teknik analisis deskriptif. Subjek penelitian ini adalah siswa kelas VIII B SMP Negeri 2 Juwiring yang berjumlah 18 siswa.

\section{HASIL DAN PEMBAHASAN}

1. Deskripsi Pra Siklus

Skala motivasi belajar siswa terdiri dari enam indikator, yaitu indikator hasrat dan keinginan berhasil, dorongan dan kebutuhan dalam belajar, harapan dan cita-cita masa depan, penghargaan dalam belajar, kegiatan yang menarik dalam belajar, dan 
lingkungan belajar yang kondusif. Skala motivasi belajar diberikan kepada siswa kelas VIII B sejumlah 28 siswa, diperoleh hasil kondisi awal motivasi belajar siswa sebanyak 3 siswa berada pada kategori tinggi (prosentase antara 70\%-85\%), 7 siswa berada pada kategori sedang (prosentase antara 55\%-70\%), dan 18 siswa berada pada kategori rendah (prosentase antara 40\%-55\%). Oleh karena itu subyek penelitian ini terdiri dari 18 siswa kelas VIII B yang motivasi belajarnya rendah dengan prosentase antara $40 \%-55 \%$.

\section{Deskripsi Siklus I}

Siklus I terdiri dari empat kegiatan, yaitu : 1) perencanaan (membuat kesepakatan dengan siswa mengenai waktu pelaksanaan layanan, menyiapkan Rencana Pelaksanaan Layanan (RPL) dan materi layanan yang terdiri dari definisi dan jenis motivasi belajar, menyiapkan perangkat multimedia, menyiapkan lembar observasi dan menyiapkan lembar evaluasi; 2) tindakan (pendahuluan, kegiatan inti dan penutup); 3) observasi; dan 4) refleksi.

Tabel 1. Hasil Observasi pada Siklus I Pertemuan Pertama

\begin{tabular}{|c|c|c|c|c|}
\hline No & Aspek Yang Diobservasi & Ada & Tidak & Keterangan \\
\hline 1 & Terbuka & V & \multirow{5}{*}{ V } & $\begin{array}{l}\text { beberapa siswa masih } \\
\text { tertutup }\end{array}$ \\
\hline 2 & Komunikatif & V & & $\begin{array}{lr}\text { masih banyak siswa } \\
\text { yang } & \text { malu } \\
\text { mengemukakan } & \\
\text { pendapatnya } & \end{array}$ \\
\hline 3 & Antusias & & & siswa belum antusias \\
\hline 4 & Terlihat senang, nyaman & V & & $\begin{array}{l}\text { beberapa siswa terlihat } \\
\text { senang dan nyaman }\end{array}$ \\
\hline 5 & $\begin{array}{l}\text { Mampu mengambil } \\
\text { pelajaran dari tayangan } \\
\text { yang disajikan }\end{array}$ & V & & $\begin{array}{l}\text { masih sedikit siswa } \\
\text { yang dapat mengambil } \\
\text { pelajaran dari tayangan } \\
\text { yang disajikan. }\end{array}$ \\
\hline
\end{tabular}

Tabel 2. Hasil Observasi pada Siklus I Pertemuan Kedua 


\begin{tabular}{|c|c|c|c|}
\hline No & Aspek Yang Diobservasi & Ada Tidak & Keterangan \\
\hline 1 & Terbuka & $\mathrm{V}$ & siswa mulai terbuka \\
\hline 2 & Komunikatif & V & $\begin{array}{ll}\text { beberapa } & \text { siswa } \\
\text { mampu } & \\
\text { mengemukakan } & \\
\text { pendapatnya } & \end{array}$ \\
\hline 3 & Antusias & V & siswa mulai antusias \\
\hline 4 & $\begin{array}{l}\text { Terlihat senang, nyaman } \\
\text { Mampu mengambil }\end{array}$ & V & $\begin{array}{l}\text { siswa terlihat senang } \\
\text { dan nyaman }\end{array}$ \\
\hline 5 & $\begin{array}{l}\text { pelajaran dari tayangan } \\
\text { yang disajikan }\end{array}$ & V & $\begin{array}{l}\text { banyak siswa yang } \\
\text { mulai mampu } \\
\text { mengambil pelajaran } \\
\text { dari tayangan yang } \\
\text { disajikan. }\end{array}$ \\
\hline
\end{tabular}

Tabel 3. Deskripsi Siklus I

\begin{tabular}{|c|c|c|c|c|c|c|c|c|c|}
\hline No & $\begin{array}{l}\text { Kode } \\
\text { Siswa }\end{array}$ & Skor & $\begin{array}{l}\text { Pro } \\
\text { sen } \\
\text { tase } \\
\end{array}$ & $\begin{array}{c}\text { Kate } \\
\text { gori }\end{array}$ & No & $\begin{array}{c}\text { Ko } \\
\text { de Sis } \\
\text { wa } \\
\end{array}$ & Skor & $\begin{array}{l}\text { Pro } \\
\text { sen } \\
\text { tase } \\
\end{array}$ & $\begin{array}{l}\text { Kate } \\
\text { gori }\end{array}$ \\
\hline 1 & S1 & 90 & $58 \%$ & Sedang & 10 & S15 & 82 & $53 \%$ & Rendah \\
\hline 2 & $\mathrm{~S} 2$ & 93 & $60 \%$ & Sedang & 11 & S16 & 101 & $65 \%$ & Sedang \\
\hline 3 & S4 & 110 & $71 \%$ & Tinggi & 12 & S19 & 99 & $63 \%$ & Sedang \\
\hline 4 & S6 & 96 & $62 \%$ & Sedang & 13 & S21 & 94 & $60 \%$ & Sedang \\
\hline 5 & S8 & 97 & $62 \%$ & Sedang & 14 & $\mathrm{~S} 23$ & 93 & $60 \%$ & Sedang \\
\hline 6 & S9 & 111 & $71 \%$ & Tinggi & 15 & S24 & 112 & $72 \%$ & Tinggi \\
\hline 7 & S11 & 106 & $68 \%$ & Sedang & 16 & S25 & 101 & $65 \%$ & Sedang \\
\hline 8 & S12 & 108 & $69 \%$ & Sedang & 17 & S26 & 84 & $54 \%$ & Rendah \\
\hline 9 & S14 & 92 & $59 \%$ & Sedang & 18 & S28 & 111 & $71 \%$ & Tinggi \\
\hline \multicolumn{4}{|c|}{ Jumlah } & & \multicolumn{5}{|c|}{1.780} \\
\hline \multicolumn{4}{|c|}{ Rata-rata } & & & & 99 & $63 \%$ & Sedang \\
\hline
\end{tabular}

3. Deskripsi Siklus II

Siklus II mencakup empat kegiatan, yaitu : 1) perencanaan (membuat kesepakatan dengan siswa mengenai waktu pelaksanaan layanan, menyiapkan Rencana Pelaksanaan Layanan (RPL) dan materi layanan yang terdiri dari definisi dan jenis motivasi belajar, menyiapkan perangkat multimedia, menyiapkan lembar observasi dan menyiapkan lembar evaluasi; 2) tindakan (pendahuluan, kegiatan inti dan penutup); 3) observasi; dan 4) refleksi. 
Tabel 4. Hasil Observasi pada Siklus II Pertemuan Pertama

\begin{tabular}{|c|c|c|c|c|}
\hline No & Aspek Yang Diobservasi & Ada & Tidak & Keterangan \\
\hline 1 & Terbuka & $\mathrm{V}$ & & siswa terbuka \\
\hline 2 & Komunikatif & $\mathrm{V}$ & & $\begin{array}{l}\text { siswa mampu } \\
\text { mengemukakan } \\
\text { pendapatnya }\end{array}$ \\
\hline 3 & Antusias & $\mathrm{V}$ & & siswa antusias \\
\hline 4 & $\begin{array}{l}\text { Terlihat senang, nyaman } \\
\text { Mampu }\end{array}$ & $\mathrm{V}$ & & $\begin{array}{l}\text { siswa terlihat senang } \\
\text { dan nyaman }\end{array}$ \\
\hline 5 & $\begin{array}{l}\text { pelajaran dari tayangan } \\
\text { yang disajikan }\end{array}$ & $\mathrm{V}$ & & $\begin{array}{l}\text { banyak siswa mampu } \\
\text { mengambil pelajaran } \\
\text { dari tayangan yang } \\
\text { disajikan. }\end{array}$ \\
\hline
\end{tabular}

Tabel 5. Hasil Observasi pada Siklus II Pertemuan Kedua

\begin{tabular}{|c|c|c|c|}
\hline No & Aspek Yang Diobservasi & Ada & Keterangan \\
\hline 1 & Terbuka & V & $\begin{array}{c}\text { semua } \\
\text { terbuka }\end{array}$ \\
\hline 2 & Komunikatif & V & $\begin{array}{l}\text { semua siswa mampu } \\
\text { mengemukakan } \\
\text { pendapatnya }\end{array}$ \\
\hline 3 & Antusias & V & semua siswa antusias \\
\hline 4 & $\begin{array}{l}\text { Terlihat } \\
\text { nyaman }\end{array}$ & V & $\begin{array}{l}\text { siswa terlihat senang } \\
\text { dan nyaman }\end{array}$ \\
\hline 5 & $\begin{array}{l}\text { Mampu mengambil } \\
\text { pelajaran dari tayangan } \\
\text { yang disajikan }\end{array}$ & V & $\begin{array}{l}\text { semua siswa mampu } \\
\text { mengambil pelajaran } \\
\text { dari tayangan yang } \\
\text { disajikan. }\end{array}$ \\
\hline
\end{tabular}

Tabel 6. Deskripsi Siklus II

\begin{tabular}{cccccccccc}
\hline No & $\begin{array}{c}\text { Ko } \\
\text { de } \\
\text { Sis } \\
\text { wa }\end{array}$ & Skor & $\begin{array}{c}\text { Pro } \\
\text { sen } \\
\text { tase }\end{array}$ & $\begin{array}{c}\text { Kate } \\
\text { gori }\end{array}$ & No & $\begin{array}{c}\text { Ko } \\
\text { de } \\
\text { Sis } \\
\text { wa }\end{array}$ & Skor & $\begin{array}{c}\text { Pro } \\
\text { sen } \\
\text { tase }\end{array}$ & $\begin{array}{c}\text { Kate } \\
\text { gori }\end{array}$ \\
\hline 1 & S1 & 117 & $75 \%$ & Tinggi & 10 & S15 & 106 & $68 \%$ & Sedang \\
2 & S2 & 114 & $73 \%$ & Tinggi & 11 & S16 & 128 & $82 \%$ & Tinggi \\
3 & S4 & 125 & $80 \%$ & Tinggi & 12 & S19 & 123 & $79 \%$ & Tinggi \\
4 & S6 & 108 & $69 \%$ & Sedang & 13 & S21 & 131 & $84 \%$ & Tinggi \\
5 & S8 & 108 & $69 \%$ & Sedang & 14 & S23 & 106 & $68 \%$ & Sedang \\
6 & S9 & 129 & $83 \%$ & Tinggi & 15 & S24 & 131 & $84 \%$ & Tinggi \\
7 & S11 & 119 & $76 \%$ & Tinggi & 16 & S25 & 108 & $69 \%$ & Sedang \\
8 & S12 & 125 & $80 \%$ & Tinggi & 17 & S26 & 103 & $66 \%$ & Sedang
\end{tabular}




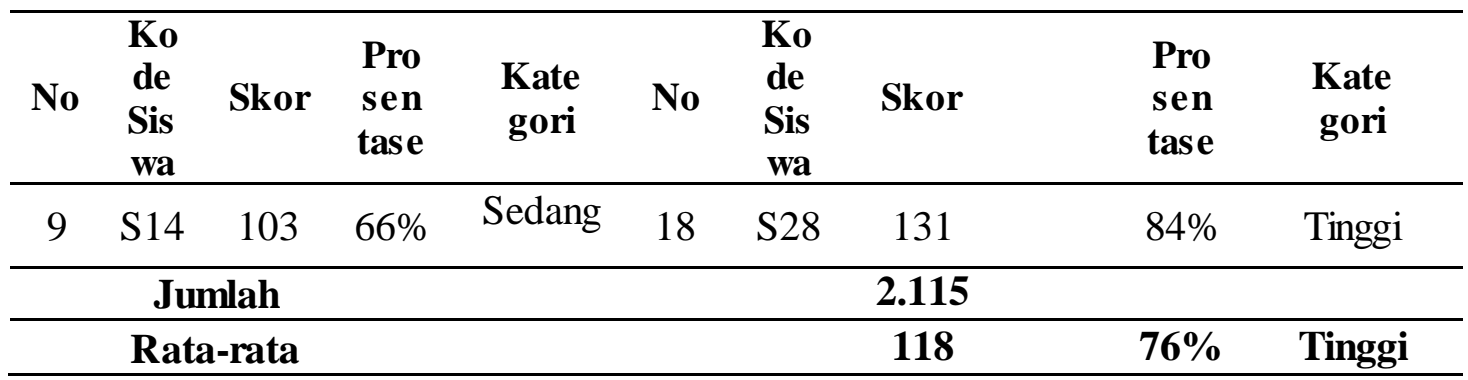

Berdasarkan data yang sudah dipaparkan di atas, ternyata motivasi belajar siswa mengalami peningkatan. Pada saat pengukuran prasiklus, prosentase skor yang dimiliki siswa berada pada rentang antara 40\% - 55\% dengan kategori rendah. Kemudian setelah layanan PKo dengan teknik multimedia siklus I dan II diberikan, prosentase skor yang dimiliki oleh siswa mengalami kenaikan. Hasil akhir pada siklus II berkisar antara $70 \%$ - $85 \%$ dengan kategori tinggi.

Tabel 7. Rekapitulasi Hasil Pengukuran Motivasi Belajar

\begin{tabular}{|c|c|c|c|c|c|c|c|}
\hline \multirow[b]{2}{*}{ No } & \multirow{2}{*}{$\begin{array}{l}\text { Kode } \\
\text { Sis wa }\end{array}$} & \multicolumn{2}{|c|}{ Prasiklus } & \multicolumn{2}{|c|}{ Siklus I } & \multicolumn{2}{|c|}{ Siklus II } \\
\hline & & $\begin{array}{l}\text { Prose } \\
\text { ntase }\end{array}$ & Kategori & $\begin{array}{l}\text { Prose } \\
\text { ntase }\end{array}$ & Kategori & $\begin{array}{l}\text { Prose } \\
\text { ntase }\end{array}$ & Kategori \\
\hline 1 & S1 & $48 \%$ & Rendah & $58 \%$ & Sedang & $75 \%$ & Tinggi \\
\hline 2 & S2 & $51 \%$ & Rendah & $60 \%$ & Sedang & $73 \%$ & Tinggi \\
\hline 3 & S4 & $44 \%$ & Rendah & $71 \%$ & Tinggi & $80 \%$ & Tinggi \\
\hline 4 & S6 & $45 \%$ & Rendah & $62 \%$ & Sedang & $69 \%$ & Sedang \\
\hline 5 & S8 & $53 \%$ & Rendah & $62 \%$ & Sedang & $69 \%$ & Sedang \\
\hline 6 & S9 & $42 \%$ & Rendah & $71 \%$ & Tinggi & $83 \%$ & Tinggi \\
\hline 7 & S11 & $44 \%$ & Rendah & $68 \%$ & Sedang & $76 \%$ & Tinggi \\
\hline 8 & $\mathrm{~S} 12$ & $51 \%$ & Rendah & $69 \%$ & Sedang & $80 \%$ & Tinggi \\
\hline 9 & S14 & $54 \%$ & Rendah & $59 \%$ & Sedang & $66 \%$ & Sedang \\
\hline 10 & S15 & $41 \%$ & Rendah & $53 \%$ & Rendah & $68 \%$ & Sedang \\
\hline 11 & S16 & $41 \%$ & Rendah & $65 \%$ & Sedang & $82 \%$ & Tinggi \\
\hline 12 & S19 & $40 \%$ & Rendah & $63 \%$ & Sedang & $79 \%$ & Tinggi \\
\hline 13 & S21 & $53 \%$ & Rendah & $60 \%$ & Sedang & $84 \%$ & Tinggi \\
\hline 14 & S23 & $54 \%$ & Rendah & $60 \%$ & Sedang & $68 \%$ & Sedang \\
\hline 15 & S24 & $52 \%$ & Rendah & $72 \%$ & Tinggi & $84 \%$ & Tinggi \\
\hline 16 & S25 & $48 \%$ & Rendah & $65 \%$ & Sedang & $69 \%$ & Sedang \\
\hline 17 & S26 & $45 \%$ & Rendah & $54 \%$ & Rendah & $66 \%$ & Sedang \\
\hline
\end{tabular}




\begin{tabular}{cccccccc}
18 & S28 & $46 \%$ & Rendah & $71 \%$ & Tinggi & $84 \%$ & Tinggi \\
\hline $\begin{array}{l}\text { Rata- } \\
\text { rata }\end{array}$ & $\mathbf{5 4 \%}$ & Rendah & $\mathbf{6 3 \%}$ & Sedang & $\mathbf{7 6 \%}$ & Tinggi \\
\hline
\end{tabular}

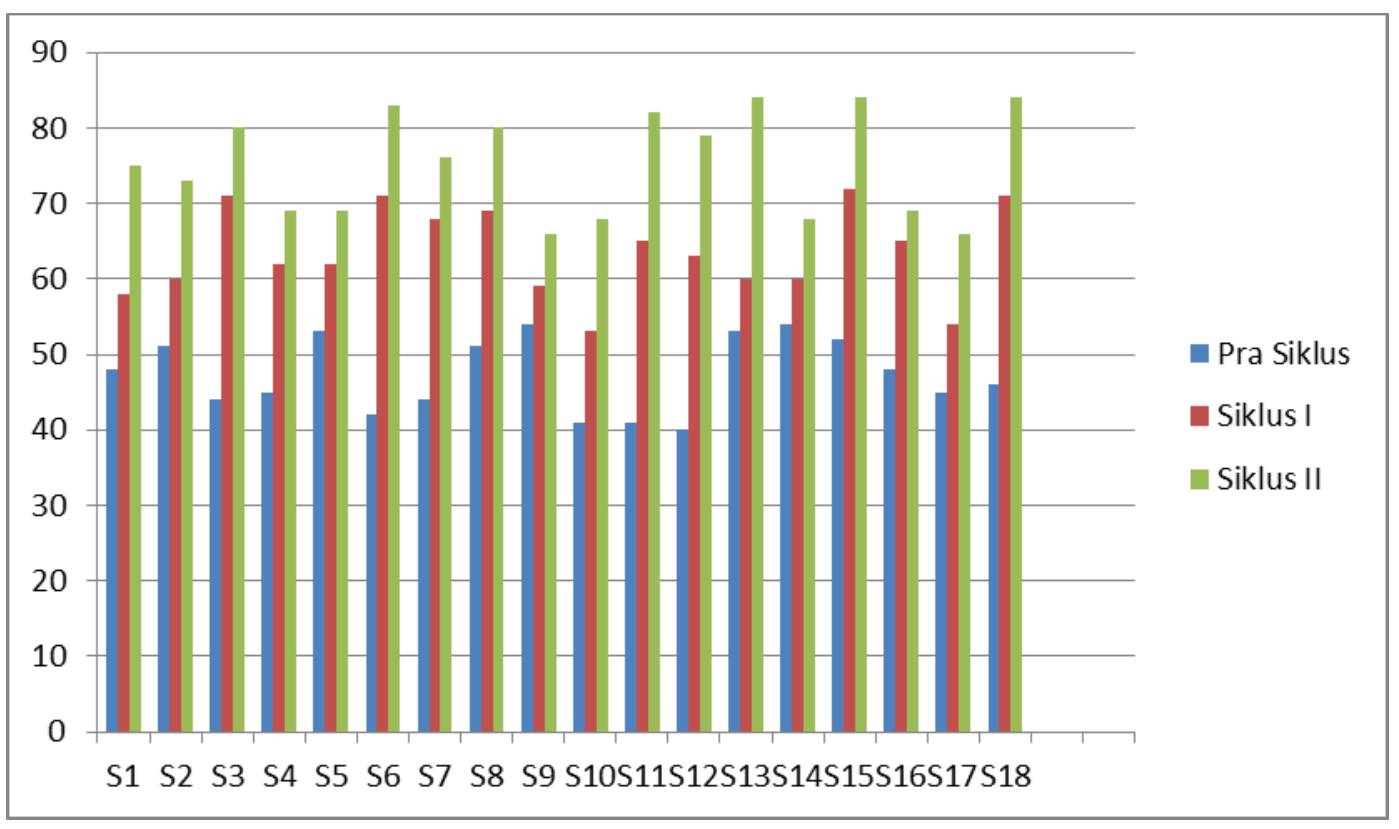

Gambar 1. Grafik Hasil Pengukuran Motivasi Belajar

Penelitian yang dilakukan oleh Aprilia (2017) mendapatkan hasil bahwa terdapat pengaruh yang positif layanan penguasaan konten terhadap motivasi belajar siswa di MTsN Kota Tanjungbalai. Sejalan dengan penelitian tersebut, Sukmana, Fitriyanti dan Fijriani (2019) melakukan penelitian yang menunjukkan hasil bahwa layanan penguasaan konten berpengaruh terhadap motivasi belajar pada siswa kelas VIII SMPN 01 Cileungsi. Pranoto (2013) melakukan penelitian terhadap siswa kelas VII.4 SMP Negeri 1 Metro yang menunjukkan bahwa melalui layanan penguasan konten dapat meningkatkan motivasi belajar siswa. Hasil ketiga penelitian tersebut sejalan dengan hasil penelitian ini. Perbedaannya adalah jika dalam ketiga penelitian tersebut meneliti tentang pengaruh layanan penguasaan konten secara umum terhadap motivasi belajar siswa tetapi dalam penelitian ini meneliti pengaruh layanan penguasaan konten dengan teknik multimedia. Ketiga penelitian tersebut dan penelitian ini sama-sama menunjukkan hasil bahwa melalui layanan penguasaan konten dapat meningkatkan motivasi belajar siswa.

Amalia ( 2017) melakukan penelitian terhadap siswa SD kelas V yang menunjukkan hasil bahwa motivasi belajar siswa sebelum dan sesudah diberikan layanan penguasan konten teknik mind mapping mengalami peningkatan sebesar 9,23\%. 
Penelitian yang serupa dilakukan oleh Hariyadi (2012) terhadap siswa kelas XII IPA 2 SMA N 2 Ungaran yang menunjukkan hasil bahwa motivasi belajar siswa SMA Negeri

2 Ungaran dapat ditingkatkan melalui layanan penguasaan konten dengan dukungan tampilan kepustakaan berbasis TIK. Hasil penelitian dari kedua penelitian tersebut sejalan dengan penelitian ini, yaitu melalui layanan penguasaan konten dapat meningkatkan motivasi belajar siswa. Perbedaannya adalah penelitian ini menggunakan layanan penguasaan konten dengan teknik multimedia, sedangkan penelitian yang dilakukan oleh Amalia (2017) dan Hariyadi (2012) menggunakan layanan penguasaan konten dengan teknik yang berbeda, yaitu mind mapping dan dukungan tampilan kepustakaan berbasis TIK.

Puspitasari (2016) melakukan penelitian terhadap siswa kelas II SDN Tlogoadi yang menunjukkan hasil bahwa terjadi peningkatan motivasi belajar siswa melalui penggunaan media film pada mata pelajaran PKn. Penelitian tersebut sejalan dengan penelitian ini, yaitu sama-sama menggunakan media film. Perbedaannya adalah dalam penelitian tersebut hanya menggunakan media film sedangkan dalam penelitian ini menggunakan teknik multimedia, yaitu film dan power point. Dari semua penelitian diatas memiliki persamaan yaitu melalui layanan penguasaan konten dapat meningkatkan motivasi belajar siswa.

\section{KESIMPULAN}

Kesimpulan dari penelitian ini yaitu : 1) motivasi belajar siswa kelas VIII B SMP Negeri 2 Juwiring sebelum guru memberikan layanan penguasaan konten dengan teknik multimedia berada pada kategori rendah dengan prosentase skor antara $40 \%$ $55 \%$; 2) setelah peneliti memberikan layanan penguasaan konten dengan teknik multimedia maka motivasi belajar siswa kelas VIII B SMP Negeri 2 Juwiring berada pada kategori tinggi dengan prosentase skor antara $70 \%-85 \%$; 3) terdapat perubahan yang positif yaitu berupa peningkatan yang signifikan pada motivasi belajar siswa setelah diberi layanan penguasaan konten dengan teknik multimedia. Maka dengan demikian layanan penguasaan konten dengan teknik multimedia dapat meningkatkan motivasi belajar siswa.

Berdasarkan hasil penelitian yang didapatkan dalam penelitian ini maka peneliti memberikan saran: 1) bagi konselor, layanan penguasaan konten dengan teknik multimedia dapat diterapkan sebagai salah satu model layanan untuk meningkatkan kemampuan siswa dalam menguasai suatu konten tertentu; 2) bagi subjek penelitian diharapkan dapat meningkatkan motivasi belajarnya; dan 3) bagi peneliti selanjutnya 
diharapkan dapat meningkatkan kualitas penelitian dengan menggunakan metode pengumpulan data yang lebih lengkap, misalnya ditambah dengan wawancara agar dapat mengungkap hal-hal yang tidak dapat diungkap menggunakan skala psikologi.

\section{DAFTAR PUSTAKA}

Amalia, R.U. (2017). Pengaruh Layanan Penguasan Konten Teknik Mind Mapping terhadap Motivasi Belajar Siswa. Indonesian Journal of Guidance and Counseling : Theory and Application, 6(3), 53-59.

Aprilia, L. (2017). "Pengaruh Layanan Penguasaan Konten terhadap Motivasi Belajar Siswa MTsN Tanjungbalai Tahun Ajaran 2016/2017". Skripsi. Medan : Universitas Islam Negeri Sumatera Utara.

Dimyati. (2016). Belajar dan Pembelajaran. Jakarta : Bumi Aksara.

Hariyadi, Sigit. (2012). Meningkatkan Motivasi Belajar Melalui Layanan Penguasaan Konten Dukungan Tampilan Kepustakaan Berbasis TIK. Indonesian Journal of Guidance and Counseling : Theory and Application, 1(1), 50-56.

Khodijah, N. (2017). Psikologi Pendidikan. Jakarta: Rajagrafindo Persada.

Pranoto, H. (2013). Effort to Improve Learning Motivation of Student with Content Mastery in SMP Negeri 1 Metro. Guidena : Jurnal Ilmu Pendidikan, Psikologi, Bimbingan dan Konseling, 3(1), 31-41.

Prayitno. (2016). Layanan Penguasaan Konten. Padang : Jurusan Bimbingan dan Konseling FIP Universitas Negeri Padang.

Puspitasari, R.D. (2016). Peningkatan Motivasi Belajar Pkn Siswa Kelas II SDN Tlogoadi Melalui Media Film. Jurnal Pendidikan Guru Sekolah Dasar, 28(5), 2.687-2.694.

Santrock, J.W. (2015). Psikologi Pendidikan Edisi Kedua. Jakarta: Kencana.

Sardiman, A.M. (2018). Interaksi dan Motivasi Belajar Mengajar. Jakarta: Rajawali.

Sukmana, R.S., Fitriyanti, E., \& Fijriani. (2019). Pengaruh Layanan Penguasaan Konten terhadap Tingkatnya Motivasi Belajar pada Siswa Kelas VIII SMPN 01 Cileungsi. Teraputik, 2(3), 156-164.

Tohirin. (2017). Bimbingan dan Konseling di Sekolah dan Madrasah (Berbasis Integrasi). Jakarta : PT. Raja Grafindo Persada.

Uno, H.B. (2017). Teori Motivasi dan Pengukurannya. Jakarta : PT Bumi Aksara.

Usman, M.U. (2018). Menjadi Guru Profesional. Bandung : PT Remaja Rosdakarya. 